\title{
Mediasi Kebijakan Deviden pada Pengaruh Profitabilitas terhadap Nilai Perusahaan BUMN yang Listing Periode 2014-2018
}

\author{
Sukirno \\ Fakultas Ekonomi dan Bisnis - Universitas Serang Raya \\ e-mail: sukirno79@gmail.com
}

\begin{abstract}
Profitability and dividend policy viewed with signaling theory has information content so that it can affect the value of the company. The purpose of this study is to examine the mediation of dividend policy on the effect of profitability on the value of listed SOEs in the 2014-2018 period. Research samples of 13 companies were taken using a purposive sampling technique with several criteria according to research needs. The research method uses a quantitative approach with simple regression analysis tools and sobel tests. This study shows that partially profitability has a significant effect on firm value, profitability has a significant effect on dividend policy, while dividend policy does not affect firm value. this study also shows that dividend policy cannot mediate the effect of profitability on firm value.
\end{abstract}

Keywords: profitability, company value, dividend policy, signaling theory

\begin{abstract}
Abstrak
Profitabilitas dan kebijakan deviden jika dilihat dengan signalling theory memiliki kandungan informasi sehingga dapat mempengaruhi nilai perusahaan. Tujuan dari penelitian ini adalah menguji mediasi kebijakan deviden pada pengaruh profitabilitas terhadap nilai perusahaan BUMN yang listing pada periode 2014-2018. Sampel penelitian sebanyak 13 perusahaan diambil menggunakan teknik purposive sampling dengan beberapa kriteria sesuai kebutuhan penelitian. Metode penelitian menggunakan pendekatan kuantitatif dengan alat analisis regresi sederhana dan uji sobel. Penelitian ini menunjukan bahwa secara parsial profitabilitas berpengaruh signifikan terhadap nilai perusahaan, profitabilitas berpengaruh signifikan terhadap kebijakan deviden, sedangkan kebijakan deviden tidak berpengaruh terhadap nilai perusahaan. penelitian ini juga menunjukan bahwa kebijakan deviden tidak dapat memediasi pengaruh profitabilitas terhadap nilai perusahaan.
\end{abstract}

Kata kunci: profitabilitas, nilai perusahaan, kebijakan deviden, teori sinyal 


\section{PENDAHULUAN}

Nilai perusahaan adalah persepsi investor terhadap tingkat keberhasilan perusahaan yang dicerminkan oleh harga sahamnya (Wiyono \& Kusuma, 2017). Semakin tinggi harga saham perusahaan akan meningkatkan nilai perusahaannya dan semakin baik persepsi investor terhadap prospek perusahaan, semakin menurun harga saham perusahaan maka akan menurunkan nilai perusahaannya dan semakin buruk persepsi investor terhadap prospek perusahaan di masa yang akan datang. Dengan demikian berarti bahwa keberhasilan kineja manajemen perusahaan dapat diukur dengan kemampuannya dalam meningkatkan nilai perusahaan.

Salah satu cara mengukur nilai perusahaan adalah dengan rasio Price to Book Value (PBV). Menurut Murhadi (2013), PBV adalah perbandingan antara harga pasar saham dan nilai buku ekuitas sebagaimana yang ada di laporan posisi keuangan. Harga pasar adalah harga yang terjadi dari proses tawar menawar harga saham di pasar modal dan bisa ditentukan jika saham perusahaan dijual di pasar modal, sedang nilai buku adalah nilai perusahaan yang dihitung dengan dasar konsep akuntansi yaitu dihitung dengan membagi selisih antar total aset dan total utang dengan jumlah saham yang beredar.
Menurut Permata dkk. (2013), nilai saham dikatakan undervalued ketika nilai PBV berada di bawah 1, dan overvalued ketika nilai PBV berada di atas 1 .

Idealnya setiap manajer keuangan perusahan harus mampu meningkatkan harga saham perusahaannya agar nilai perusahaan naik dan kesejahteraan pemilik dapat terpenuhi, namun tidak jarang terjadi justru harga saham dari waktu ke waktu cenderung menurun sehingga tujuan perusahaan dalam mensejahterakan pemilik tidak tercapai. Fenomena tersebut terjadi juga pada perusahaan-perusahaan Badan Usaha Milik Negara (BUMN) yang listing di Bursa Efek Indonesia (BEI) seperti terlihat pada Gambar 1.

Gambar 1 menunjukkan bahwa nilai perusahaan industri BUMN yang listing di BEI periode 2014-2018 belum sesuai harapan, terlihat nilai PBV pada periode tersebut cenderung menurun dari tahun ke tahun, bahkan pada tahun 2017 dan tahun 2018 nilainya lebih kecil dari satu, artinya harga saham sangat rendah, pasar (investor) menilai perusahaan lebih kecil dari nilai buku per lembar sahamnya. Secara ratarata industri ini memiliki masalah pada nilai perusahaannya.

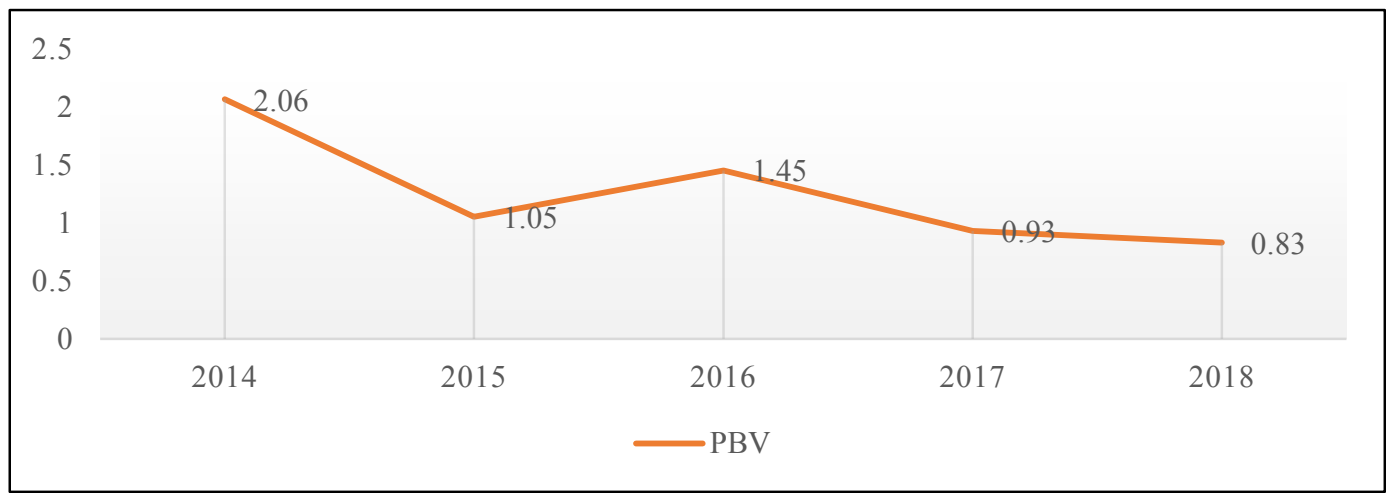

Gambar 1. Rata-Rata Nilai PBV Industri BUMN yang Listing di BEI Periode 2014-2018

Sumber: Data diolah dari situs BEI menggunakan Ms. Exel 
Menurut Brigham \& Houston (2010), tinggi rendahnya nilai perusahaan dipengaruhi oleh beberapa faktor diantaranya seperti tingkat profitabilitas, likuiditas, manajemen aset, dan rasio utang. Sementara menurut pendapat Sujoko \& Soebiantoro (2007), profitabilitas menjadi pertimbangan yang cukup penting bagi investor dalam mengambil keputusan investasi. Profit yang tinggi dapat memberikan indikasi prospek perusahaan yang baik, sehingga dapat meningkatkan minat investor untuk membeli saham perusahaan. Peningkatan permintaan pasar terhadap saham perusahaan akan meningkatkan harga sahamnya dan secara otomatis akan dapat meningkatkan nilai perusahaan.

Hubungan profitabilitas dengan nilai perusahaan didukung oleh teori sinyal, dimana meningkatnya profitabilitas perusahaan akan memberikan sinyal positif terhadap investor bahwa perusahaan dalam keadaan baik, investor akan memberikan respon positif dengan membeli saham perusahaan sehingga nilai perusahaan meningkat. Profitabilitas yang dihasilkan oleh perusahaan merupakan cerminan dari kemampuan perusahaan dalam menghasilkan labanya, ketika perusahaan mengumumkan bahwa profitabilitas perusahaan meningkat maka harga saham akan merespon informasi yang diberikan oleh perusahaan (Wiyono \& Kusuma, 2017).

Bukti empiris pengaruh profitabilitas terhadap nilai perusahaan ditunjukkan oleh hasil penelitian Puspitaningtyas (2017), Daviana \& Fitria (2017) serta Sinarmayarani \& Suwitho (2016) yang membuktikan bahwa profitabilitas memiliki pengaruh positif signifikan terhadap nilai perusahaam tetapi hubungan tersebut juga ditentang oleh hasil penelitian Nur (2018) dan Oktrima (2017) yang membuktikan bahwa tidak ada pengaruh signifikan antara profitabilitas terhadap nilai perusahaan. Perbedaan hasil penelitian tersebut menunjukkan masih adanya gap penelitian mengenai hubungan profitabilitas dan nilai perusahaan.

Tingkat profitabilitas perusahaan pada umumnya akan dijadikan dasar dalam pembagian deviden. Semakin besar profit yang dihasilkan oleh perusahaan, semakin besar pula kemungkinan deviden yang akan dibagikan kepada pemegang saham, begitupun sebaliknya semakin kecil profit yang dihasilkan perusahaan, semakin kecil pula kemungkinan jumlah deviden yang akan dibagikan kepada pemegang saham, dengan demikian profitabilitas dapat mempengaruhi kebijakan deviden. Sejalan dengan pendapat Hanafi (2015) bahwa ada sejumlah faktor yang mempengaruhi naik turunnya jumlah deviden yang dibagikan kepada pemegang saham diantaranya adalah profitabilitas, likuiditas, akses ke pasar keuangan dan stabilitas. Hubungan dua variabel tersebut didukung oleh hasil penelitian Nur (2018) dan Sinarmayarani \& Suwitho (2016) yang membuktikan bahwa profitabilitas berpengaruh positif signifikan terhadap kebijakan deviden. Di sisi lain, hasil penelitian Andriani (2018) dan Daviana \& Fitria (2017) yang membuktikan bahwa profitabilitas tidak berpengaruh signifikan terhadap kebijakan deviden.

Kebijakan deviden yang diterapkan perusahaan tidak luput dari pertimbangan investor dalam mengambil keputusan investasi. Hubungan kebijakan deviden dengan nilai perusahaan menurut Brigham \& Houston (2010) dapat dijelaskan melalui signalling theory. Berdasarkan signalling theory, investor menganggap setiap terjadi perubahan dividen merupakan isyarat dan prakiraan manajemen atas kondisi laba yang dihasilkannya. Semakin besar jumlah dividen yang dibagikan secara proporsional kepada para pemegang saham maka hal tersebut merupakan isyarat positif bagi investor terhadap kinerja manajemen di masa yang akan datang yang diyakini akan mampu 
menciptakan keuntungan yang lebih besar, hal ini tentunya akan menarik bayak peminat (investor) untuk membeli saham perusahaan, peningkatan permintaan terhadap saham akan meningkatkan harga saham dan nilai perusahaanya. Sebaliknya jika perusahaan mengurangi tingkat pembayaran dividen atau bahkan tidak membayar dividen maka akan menjadi sinyal negatif bagi investor terhadap kinerja manajemen di masa yang akan datang, hal tersebut tentunya akan menurunkan minat investor untuk membeli saham perusahaan, dengan demikian patut diduga kebijakan deviden mempengaruhi nilai perusahaan.

Ada dukungan empiris hubungan kebijakan deviden dengan nilai perusahaan. Putra \& Lestari (2016) menguji 20 sampel perusahaan manufaktur yang listing periode 2010-2013 menyatakan bahwa kebijakan deviden berpengaruh signifikan terhadap nilai perusahaan. Alamsyah (2017) menguji perusahaan-perusahaan yang teindex kompas 100 periode listing 2010-2013 membuktikan bahwa kebijakan deviden berpengaruh tetapi tidak signifikan terhadap nilai perusahaan. Martha dkk. (2018) menguji 30 sampel perusahaan perbankan menyatakan bahwa kebijakan deviden berpengaruh negatif tidak signifikan. Rachmawati \& Pinem (2015) menguji 55 sampel perusahaan manufaktur sektor kimia periode listing 2013-2014 dan membuktikan bahwa kebijakan deviden tidak memiliki pengaruh terhadap nilai perusahaan.

Dukungan empiris mengenai posisi kebijakan deviden dapat memediasi pengaruh profitabilitas terhadap nilai perusahaan ditunjukkan oleh hasil penelitian Sinarmayarani \& Suwitho (2016) yang menguji 11 sampel perusahaan food and beverage yang listing pada periode 20102014 menyatakan bahwa profitabilitas berpengaruh secara tidak langsung terhadap nilai perusahaan melalui kebijakan dividen serta hasil penelitian Deviana \& Fitria (2017) yang menguji 20 sampel perusahaan manufaktur yang listing pada periode 20112014 menyatakan bahwa kebijakan dividen dapat memediasi pengaruh profitabilitas terhadap nilai perusahaan. Namun demikian, bukti empiris lainnya menentang hasil penelitian tersebut, seperti hasil penelitian yang dilakukan oleh Nur (2018) yang menguji sampel 42 perusahaan manufaktur yang listing pada periode 2014-2017 menyatakan bahwa kebijakan deviden tidak mampu secara signifikan memediasi pengaruh profitabilitas terhadap nilai perusahaan.

Berdasarkan masih ditemukannya gap fenomena dan gap penelitian maka peneliti tertarik untuk melakukan penelitian lebih lanjut dengan mengajukan empat hipotesis penelitian sebagai berikut:

H1: Profitabilitas berpengaruh positif dan signifikan terhadap nilai perusahaan

H2: Profitabilitas berpengaruh positif dan signifikan terhadap kebijakan deviden

H3: Kebijakan deviden berpengaruh positif dan signifikan terhadap nilai perusahaan

H4: Kebijakan deviden memediasi pengaruh profitabilitas terhadap nilai perusahaan

Berdasarkan penjelasan latar belakang masalah tersebut maka tujuan dari penelitian ini adalah untuk menguji pengaruh profitabilitas terhadap nilai perusahaan, menguji pengaruh profitabilitas terhadap kebijakan deviden, menguji pengaruh kebijakan deviden terhadap nilai perusahaan dan menguji mediasi kebijakan deviden pada pengaruh profitabilitas terhadap nilai perusahaan.

\section{METODE PENELITIAN}

Penelitian ini menggunakan pendekatan kuantitatif dengan desain kausal, yaitu untuk menentukan pola hubungan sebab akibat antara variabel independen terhadap variabel dependen sehingga dapat menjelaskan hubungan kausal antar variabel penelitian. 


\section{Populasi dan Teknik Penarikan Sampel}

Populasi pada penelitian ini adalah semua perusahaan BUMN yang listing di Bursa Efek Indonesia dengan periode pengamatan tahun 2014-2018. Penarikan sampel dilakukan menggunakan teknik purposive sampling dengan kriteria sampel yang digunakan adalah (1) semua perusahaan BUMN yang memiliki data laporan keuangan lengkap selama peride pengamatan yaitu antara tahun 2014-2018,(2) semua perusahaan BUMN yang membagikan deviden selama periode pengamatan yaitu antara tahun 20142018 (3) semua perusahaan BUMN yang memiliki data harga saham lengkap selama periode pengamatan yaitu antara tahun 20142018.

\section{Variabel penelitian}

Ada tiga jenis variabel yang diteliti pada penelitian ini yaitu:

1. Profitabilitas (X) berfungsi sebagai variabel independen yaitu kemampuan perusahaan dalam menghasilkan laba yang diproksi dengan rasio return on equity (ROE). Menurut Kasmir (2014) ROE dapat diukur dengan rumus sebagai berikut:

$$
\text { ROE }=\frac{\text { Laba setelah pajak }}{\text { Modal sendiri }}
$$

2. Nilai Perusahaan (Y) berfungsi sebagai variabel dependen yaitu harga jual perusahaan yang bersedia beli oleh pembeli pada saat dijual, diproksi dengan rasio price book value (PBV), Menurut Murhadi (2013) PBV dapat diukur dengan rumus sebagai berikut:

$$
\mathrm{PBV}=\frac{\text { Harga Saham }}{\text { Nilai Buku }}
$$

3. Kebijakan Deviden (M) berfungsi sebagai variabel mediasi diproksi dengan dividend payout ratio (DPR). Menurut Sudana (2011) DPR dapat diukur dengan rumus:

$$
\mathrm{DPR}=\frac{\text { Dividen per lembar }}{\text { Laba per lembar }}
$$

\section{Teknik Pengumpulan Data}

Tenik pengumpulan data pada penelitian ini adalah teknik dokumentasi. Teknik dokumentasi adalah suatu cara yang digunakan untuk memperoleh data dan informasi dalam bentuk buku, arsip, dokumen, gambar, angka serta keterangan yang dapat mendukung penelitian kemudian ditelaah (Sugiyono, 2015). Jenis data pada penelitian ini adalah data sekunder, yaitu data variabel yang diambil dari laporan keuangan perusahaan yang dilaporkan oleh perusahaan sampel di Bursa Efek Indonesia pada periode pengamatan tahun 2014-2018. Pengumpulan data dilakukan dengan cara di-download secara langsung dari situs resmi Bursa Efek Indonesia (BEI) yaitu www.idx.com. Selain itu peneliti juga mengambil data sekunder pendukung penelitian lainnya dari beberapa sumber jurnal ilmiah dan buku teks.

\section{Analisis Data}

Pengujian hipotesis pada penelitian ini menggunakan analisis regresi yang dikembangkan oleh Sobel dengan menguji nilai Z. Model pola hubungan antar variabel pada penelitian ini dapat dilihat pada Gambar 2.

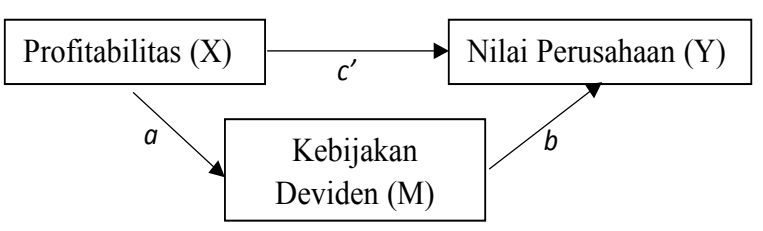

Gambar 2. Pengaruh Profitabilitas terhadap Nilai Perusahaan melalui Kebijakan Deviden

Model dirumuskan dalam bentuk persamaan regresi sebagai berikut:

$$
\begin{aligned}
& M=\beta_{0}+\beta_{1} X+\varepsilon \\
& Y=\beta_{0}+\beta_{1} X+\beta_{2} M+\varepsilon
\end{aligned}
$$


Rumus Z yang digunakan pada uji Sobel adalah sebagai berikut:

$\mathrm{Z}=\frac{a b}{\sqrt{\left(B^{2} S E_{a}^{2}\right)+\left(B^{2} S E_{a}^{2}\right)}}$

Keterangan:

$a \quad=$ Koefisien regresi variabel independen terhadap variabel mediasi

$b \quad=$ Koefisien regresi variabel independen terhadap variabel dependen

$\mathrm{SE}_{a}=$ Estimasi standard error pengaruh variabel independen terhadap variabel mediasi

$\mathrm{SE}_{b}=$ Estimasi standard error pengaruh variabel independen terhadap variabel dependen

Kriteria Uji Hipotesis persamaan (1) dengan derajat keyakinan $95 \% \quad(\alpha \quad 0,05)$ sebagai berikut:

Jika t hitung > t tabel (n-p), maka H0 ditolak, hipotesis terbukti.

Jika $\mathrm{t}$ hitung $\leq \mathrm{t}$ tabel (n-p), maka H0 diterima, hipotesis tidak terbukti.

Kriteria uji hipotesis persamaan (2) dengan derajat keyakinan $95 \% \quad(\alpha \quad 0,05)$ sebagai berikut:

Jika nilai $Z>1,96$, maka hipotesis terbukti

Jika nilai $\mathrm{Z}<1,96$, maka hipotesis tidak terbukti

\section{HASIL DAN PEMBAHASAN}

\section{Hasil Penelitian}

Jumlah populasi keseluruhan perusahaan BUMN yang terdaftar pada periode tahun 2014 sampai dengan 2018 (5 tahun) adalah sebanyak 20 perusahaan, kemudian dilakukan sampling menggunakan teknik purposive sampling dan hasilnya didapatkan 7 perusahaan tidak masuk kriteria dan 13 perusahaan masuk kriteria sampel sehingga ditetapkan oleh peneliti sampel penelitiannya adalah 13 perusahaan. Untuk mendapatkan jumlah data penelitian maka data variabel penelitian pada 13 perusahaan dikalikan dengan periode tahun pengamatan selama 5 tahun, maka didapatkan jumlah data sampel penelitian sebanyak 65 data observasi seperti terlihat pada Tabel 1.

Tabel 1. Penentuan Jumlah Sampel dan Data Observasi Penelitian

\begin{tabular}{llcc}
\hline No. & Kriteria Sampel & $\begin{array}{c}\text { Termasuk } \\
\text { Kriteria } \\
\text { Sampel }\end{array}$ & $\begin{array}{c}\text { Tidak } \\
\text { Termasuk } \\
\text { Kriteria } \\
\text { Sampel }\end{array}$ \\
\hline $1 \quad \begin{array}{l}\text { Perusahaan BUMN } \\
\text { listing di BEI } \\
\text { periode 2014-2018 }\end{array}$ & 20 & - \\
\hline 2 & $\begin{array}{l}\text { Perusahaan BUMN } \\
\text { yang menyajikan } \\
\text { data laporan } \\
\text { keuangannya } \\
\text { secara berturut- } \\
\text { turut selama peride } \\
\text { pengamatan }\end{array}$ & 19 & \\
\hline 3 & $\begin{array}{l}\text { Perusahaan BUMN } \\
\text { yang menyajikan } \\
\text { data variabel } \\
\text { penelitian secara } \\
\text { lengkap }\end{array}$ & \\
\hline Jumlah periode pengamatan 5 tahun X 13 sampel \\
perusahaan = 65 data observasi
\end{tabular}

Penelitian ini melakukan uji statistik deskriptif untuk mendeskripsikan 65 sampel data penelitian dengan menggunakan nilai rata-rata, nilai maksimum, nilai minimum dan standar deviasi dengan bantuan program SPSS. Hasil uji menunjukkan variabel profitabilitas (ROA) selama 5 tahun periode pengamatan profit tertingginya adalah $29,1 \%$ dan terrendahnya adalah $1,1 \%$ sedangkan nilai rata-rata profitnya selama 5 tahun tersebut adalah $13,6 \%$ dengan standar deviasi 0,86. Variabel kebijakan deviden (DPR) nilai tertingginya adalah 5,19 dan nilai terrendahnya adalah adalah 0,07 sedangkan nilai rata-ratanya adalah 1,98 dengan standar deviasinya sebesar 0,16 . Variabel nilai perusahaan nilai tertingginya adalah 0,58 dan terendahnya adalah 0,03 sedangkan nilai rata-ratanya adalah 0,26 dengan nilai standar deviasinya sebesar 0,018 . Hasil uji terlihat jelas pada Tabel 2. 
Tabel 2. Hasil Uji Statistik Deskriptif

\begin{tabular}{lrrr}
\hline & \multicolumn{1}{c}{ PBV } & \multicolumn{1}{c}{ ROA } & \multicolumn{1}{c}{ DPR } \\
\hline Mean &, 2660000 & 13,6192727 & 1,9825455 \\
Maximum &, 58000 & 29,16000 & 5,19000 \\
Minimum &, 03000 & 1,19000 &, 70000 \\
Std. Dev &, 01806759 &, 86091795 &, 16034437 \\
Observation & 65 & 65 & 65 \\
\hline
\end{tabular}

Penelitian kemudian diuji menggunakan analisis regresi sederhana dan uji sobel menggunakan bantuan program aplikasi statistik SPSS untuk menguji hipotesis penelitian. Hasil uji hipotesis penelitian terlihat pada Tabel 3 dan 4 .

Tabel 3. Hasil Uji Statistik Pengaruh Variabel X terhadap M

\begin{tabular}{lccccc}
\hline $\begin{array}{c}\text { Hubungan } \\
\text { variabel }\end{array}$ & $\begin{array}{c}\text { Coefficient } \\
\left(\beta_{1}\right)\end{array}$ & $\begin{array}{c}\text { Std. } \\
\text { Error }\end{array}$ & t-statistic & t-tabel & Sig \\
\hline Constant & 0,180 & 0,041 & 4,339 & & 0,000 \\
X-M & 0,006 & 0,003 & 2,227 & 1,999 & 0,010 \\
\hline
\end{tabular}

Tabel 4. Hasil Uji Statistik Hubungan Variabel M pada Pengaruh $X$ terhadap $Y$

\begin{tabular}{lcclcc}
\hline $\begin{array}{c}\text { Hubungan } \\
\text { variabel }\end{array}$ & $\begin{array}{c}\text { Coefficient } \\
\left(\beta_{1}\right)\end{array}$ & $\begin{array}{c}\text { Std. } \\
\text { Error }\end{array}$ & t-statistic & t-tabel & Sig \\
\hline Constant & 1,459 & 0,474 & 3,081 & & 0,003 \\
X-Y & 0,070 & 0,032 & 2,172 & 1,999 & 0,034 \\
M-Y & 2,531 & 1,510 & 1,676 & 1,999 & 0,099 \\
\hline
\end{tabular}

Berdasarkan data pada Tabel 3 dan 4, Persamaan (1) dan (2) dapat dirumuskan persamaan regresinya sebagai berikut:

$$
\begin{aligned}
& \mathrm{M}=0,180+0,006 \mathrm{X}+\boldsymbol{\varepsilon} \\
& \mathrm{Y}=1,459+0,070 \mathrm{X}+0,006 \mathrm{M}+\boldsymbol{\varepsilon}
\end{aligned}
$$

Berdasarkan hasil uji Persamaan (1) dan (2) maka dapat dihitung nilai Z-value yang dikembangkan oleh Sobel untuk menentukan fungsi variabel mediasinya, sebagai berikut:

$$
\begin{aligned}
& Z=\frac{a b}{\sqrt{\left(B^{2} S E_{a}^{2}\right)+\left(B^{2} S E_{a}^{2}\right)}} \\
& Z=\frac{0,006 \times 2,531}{\sqrt{\left(2,531^{2} \times 0,003^{2}\right)+\left(0,006^{2} \times 1,510^{2}\right)}} \\
& Z=\frac{0,015186}{\sqrt{0,0000576536+0,0000820836}} \\
& Z=\frac{0,015186}{\sqrt{(0,0001397372)}} \\
& Z=\frac{0,015186}{0,011821049} \\
& Z=1,28
\end{aligned}
$$

\begin{tabular}{|c|c|c|c|c|}
\hline & Hipotesis Penelitian & Hasil & $\begin{array}{l}\text { Hipotesis } \\
\text { Statistik }\end{array}$ & Keterangan \\
\hline H1 & $\begin{array}{l}\text { Profitabilitas berpengaruh signifikan } \\
\text { terhadap Nilai Perusahaan. }\end{array}$ & $\begin{array}{l}\mathrm{t} \text { statistik }>\mathrm{t} \text { tabel } \\
2,172>1,999 \\
\text { Sig } 0,034<0,05\end{array}$ & $\begin{array}{l}\text { H0 ditolak } \\
\text { Ha diterima }\end{array}$ & $\begin{array}{l}\text { Berpengaruh } \\
\text { Signifikan }\end{array}$ \\
\hline $\mathrm{H} 2$ & $\begin{array}{l}\text { Profitabilitas berpengaruh signifikan } \\
\text { terhadap kebijakan deviden }\end{array}$ & $\begin{array}{l}\mathrm{t} \text { statistik }>\mathrm{t} \text { tabel } \\
2,227>1,999 \\
\text { Sig } 0,010<0,05\end{array}$ & $\begin{array}{l}\text { H0 ditolak } \\
\text { Ha diterima }\end{array}$ & $\begin{array}{l}\text { Berpengaruh } \\
\text { Signifikan }\end{array}$ \\
\hline H3 & $\begin{array}{l}\text { Kebijakan Deviden berpengaruh } \\
\text { signifikan terhadap Nilai Perusahaan }\end{array}$ & $\begin{array}{c}\text { t statistik }<\text { t tabel } \\
1,676<1,999 \\
\text { Sig } 0,099>0,05\end{array}$ & $\begin{array}{l}\text { H0 diterima } \\
\text { Ha ditolak }\end{array}$ & $\begin{array}{c}\text { Tidak } \\
\text { berpengaruh }\end{array}$ \\
\hline $\mathrm{H} 4$ & $\begin{array}{l}\text { Kebijakan Deviden menjadi mediasi } \\
\text { pengaruh Profitabilitas terhadap } \\
\text { Nilai Perusahaan }\end{array}$ & $\mathrm{Z} 1,28<1,96$ & Ditolak & $\begin{array}{l}\text { Bukan sebagai } \\
\text { mediator }\end{array}$ \\
\hline
\end{tabular}

Berdasarkan hasil uji regresi sederhana dan uji Sobel tersebut, maka dapat ditentukan hasil uji hipotesis penelitiannya, sebagai berikut.

Tabel 5. Hasil Uji Hipotesis Penelitian 


\section{PEMBAHASAN}

\section{Statistik Deskriptif}

Dari Tabel 5 menunjukkan bahwa nilai tingkat profitabilitas perusahaan BUMN pada periode pengamatan (2014-2018) diketahui memiliki rentang data mulai dari yang terkecil (nilai minimum) sebesar $1,2 \%$ dan yang terbesar (nilai maksimum) sebesar 29,1\%. Artinya bahwa jarak kemampuan perusahaan dalam menghasilkan laba cukup lebar pada industri ini, sebagian mampu menghasilkan profit cukup tinggi tetapi sebagian lagi menghasilkan profit sangat rendah dengan rata-rata kemampuan sebesar (nilai mean) $13,6 \%$. Sementara rentang nilai perusahaan pada periode pengamatan mulai dari yang terkecil sebesar $0,03 \%$ sampai dengan yang terbesar sebesar $0,58 \%$ dengan rata-ratanya sebesar $0,26 \%$. Artinya data nilai perusahaan ini menunjukkan bahwa rentang nilai tidak terlalu lebar, tetapi kemampuan perusahaan dalam meningkatkan nilai perusahaan sangat rendah yaitu masih di bawah $1 \%$. Sementara itu, rentang nilai kebijakan deviden dari yang terkecil sebesar 0,7\% sampai dengan yang terbesar 5,1\% dengan nilai rata-ratanya sebesar $1,98 \%$. Artinya tingkat kebijakan deviden yang dilakukan oleh perusahaan masih relatif cukup rendah.

Berdasarkan hubungan deskriptif antara tingkat profitabilitas nilai perusahaan dan kebijakan deviden perusahaan BUMN pada periode pengamatan, dapat dikatakan bahwa meskipun nilai rata-rata tingkat profitabilitas relatif cukup baik, tetapi karena kebijakan deviden perusahaan dalam membagikan devidennya cukup rendah menyebabkan terjadinya sentimen negatif dari para investor atau pemegang saham sehingga berdampak pada rendahnya nilai perusahaan.

\section{Pengaruh Profitabilitas terhadap Nilai Perusahaan}

Hasil uji statistik menunjukkan nilai t-hitung positif sebesar 2,172 lebih besar dari nilai t-tabelnya sebesar 1,999 dan nilai signifikansi sebesar 0,034 lebih kecil dari 0,050 . Artinya bahwa profitabilitas berpengaruh positif signifikan terhdap nilai perusahaan. Dengan demikian hipotesis pertama penelitian dapat diterima.

Penelitian ini mendukung signalling theory dimana semakin tinggi tingkat profitabilitas dapat memberikan sinyal postif bagi para investor terhadap prospek perusahaan di masa yang akan datang. Semakin tinggi profitabilitas perusahaan maka semakin tinggi respon pasar (investor) untuk memiliki saham perusahaan. Semakin tinggi permintaan atas saham perusahaan maka dapat meningkatkan harga sahamnya. Semakin tinggi harga saham perusahaan maka tujuan perusahaan dapat tercapai yaitu memaksimumkan kekayaan para pemegang saham. Begitupun sebaliknya, semakin rendah profitabilitas perusahaan maka akan berdampak pada penurunan harga saham dan kekayaan para pemegang sahamnya dan akan menjadi sinyal negatif bagi pasar (investor) terhadap prospek perusahaan di masa depan.

Hasil penelitian ini juga mendukung hasil penelitian sebelumnya dilakukan oleh Martha dkk. (2018), Antoro \& Hermuningsih (2018), Putra \& Lestari (2016) yang membuktikan bahwa profitabilitas berpengaruh positif signifikan terhadap nilai perusahaan. Namun hasil penelitin ini tidak mendukung penelitian yang dilakukan oleh Nur (2018) dan Oktrima (2017) membuktikan bahwa profitabilitas tidak berpengaruh signifikan terhadap nilai perusahaan.

\section{Pengaruh Profitabilitas terhadap Kebijakan Deviden}

Hasil uji statistik menunjukkan nilai t-hitung positif sebesar 2,227 lebih besar dari nilai t-tabelnya sebesar 1,999 dan nilai signifikansi sebesar 0,010 lebih kecil dari 0,050 level signifikansinya. Dapat dinyatakan bahwa profitabilitas berpengaruh positif 
signifikan terhadap kebijakan deviden, dengan demikian hipotesis kedua penelitian dapat diterima.

Hasil tersebut menunjukkan bahwa semakin tinggi tingkat profitabilitas yang dihasilkan perusahaan maka akan mengakibatkan peningkatan peluang perusahaan membagikan deviden juga semakin besar. Begitupun sebaliknya, semakin rendah tingkat profitabilitas perusahaan maka dapat menurunkan peluang perusahaan membagikan deviden lebih besar. Hal ini tentunya dapat dijadikan pertimbangan bagi investor dalam mengambil keputusan investasinya terutama jenis investor yang menginginkan keuntungan yang lebih setabil dari perolehan deviden.

Hasil penelitian ini mendukung hasil penelitian sebelumnya yang dilakukan oleh Nur (2018), Sinarmayarani \& Suwitho (2016) yang juga membuktikan bahwa profitabilitas berpengaruh positif signifikan terhadap kebijakan deviden. Namun hasil penelitian ini tidak mendukung penelitian sebelumnya yang dilakukan oleh Andriani (2018) dan Daviana dan Fitria (2017) yang membuktikan bahwa profitabilitas tidak berpengaruh signifikan terhadap kebijakan deviden.

\section{Kebijakan Deviden tidak Berpengaruh Signifikan terhadap Nilai Perusahaan}

Hasil uji statistik menunjukkan nilai t-hitung positif sebesar 1,676 lebih kecil dari nilai t-tabelnya sebesar 1,999 dan nilai signifikansi sebesar 0,099 lebih besar dari 0,050 level signifikansinya. Dapat dinyatakan bahwa kebijakan deviden tidak berpengaruh signifikan terhadap nilai perusahaan. Dengan demikian, hipotesis ketiga penelitian ditolak.

Dapat diinterpretasikan bahwa tinggi rendahnya rasio kebijakan deviden yang dibagikan perusahaan kepada para pemegang saham tidak dapat mempengaruhi tinggi rendahnya rasio nilai perusahaan. Tingkat kebijakan deviden tidak mampu memberikan sinyal positif prospek perusahaan terhadap investor, kemungkinan para investor menganggap bukan kebijakan deviden yang dapat mempengaruhi nilai perusahaan tetapi hanya profitabilitas yang memberikan sinyal prospek perusahaan akan lebih baik di masa yang akan datang.

Hasil penelitian ini mendukung hasil penelitian yang dilakukan oleh Nur (2018), Sumanti \& Mangantar (2015) yang juga membuktikan bahwa kebijakan deviden tidak berpengaruh terhadap nilai perusahaan. Namun hasil penelitian ini tidak mendukung penelitian sebelumnya yang dilakukan oleh Alamsyah (2017), Putra \& Lestari (2016) yang menyatakan bahwa kebijakan deviden berpengaruh signifikan terhadap kebijakan nilai perusahaan.

\section{Kebijakan Deviden tidak Memediasi Pengaruh Profitabilitas terhadap Nilai Perusahaan}

Hasil uji statistik menunjukan nilai $\mathrm{Z}$ (Z score) sebesar 1,28 lebih kecil dari 1,96 pada taraf signifikansi 5\% sehingga dapat dinyatakan bahwa kebijakan deviden tidak mampu memediasi pengaruh profitabilitas terhadap nilai perusahaan. Dengan demikian, hipotesis keempat penelitian ditolak.

Penelitian ini menunjukkan bahwa tinggi rendahnya nilai deviden yang dibagikan kepada para pemegang saham akibat dari profit yang dihasilkan perusahaan ternyata tidak mampu menjadi perantara untuk meningkatkan nilai perusahaannya. Investor lebih terpengaruh secara langsung oleh tingkat profitabilitas perusahaan yang tinggi dalam keputusan investasinya daripada melalui perantara atau mediasi kebijakan deviden.

Hasil penelitian ini sejalan dengan hasil penelitian yang dilakukan oleh Nur (2018), Daviana dan Fitria (2017) yang juga membuktikan bahwa kebijakan 
deviden tidak mampu memedasi pengaruh profitabilitas terhadap nilai perusahaan. Namun hasil penelitian ini tidak mendukung penelitian sebelumnya yang dilakukan oleh Sinarmayarani \& Suwitho (2016) serta Deviana \& Fitria (2017) yang menyatakan bahwa kebijakan deviden mampu memediasi pengaruh profitabilitas terhadap nilai perusahaan.

\section{SIMPULAN DAN SARAN}

Profitabilitas berpengaruh positif signifikan terhadap nilai perusahaan, penelitian ini mendukung teori signaling dimana semakin tinggi tingkat profitabilitas dapat memberikan sinyal postif bagi para investor terhadap prospek perusahaan dimasa depan. Profitabilitas juga berpengaruh positif signifikan terhadap kebijakan deviden penelitian ini menunjukkan bahwa semakin tinggi tingkat profitabilitas yang dihasilkan perusahaan maka akan mengakibatkan peningkatan peluang perusahaan membagikan deviden juga semakin besar. Sementara itu, kebijakan deviden tidak berpengaruh terhadap nilai perusahaan yang artinya tinggi rendahnya tingkat deviden yang dibagikan kepada para pemegang saham tidak dapat membuat peningkatan nilai perusahaan. Kebijakan deviden juga tidak mampu memediasi pengaruh profitabilitas terhadap nilai perusahaan yang artinya tinggi rendahnya tingkat deviden yang dibagikan kepada pemegang saham tidak mampu meningkatkan pengaruh profitabilitas terhadap nilai perusahaan.

Penelitian ini telah dilakukan dengan prosedur ilmiah namun demikian masih terdapat keterbatasan pada variabelnya dimana variabel nilai perusahaan hanya diuji dengan profitabilitas dan kebijakan deviden. Selain itu, sampel penelitian juga terbatas pada perusahaan BUMN dan tidak menguji secara spesifik pengaruhnya pada skala perusahaan (perusahaan besar dan kecil).
Berdasarkan keterbatasan penelitian tersebut, peneliti memberikan saran untuk peneliti selanjutnya agar meneliti variabel lain selain profitabilitas dan kebijakan deviden dalam memprediksi variabel nilai perusahaan termasuk mempertimbangkan variabel ukuran perusahaan agar dapat membedakan pengaruh berdasarkan ukuran perusahaan.

\section{REFERENSI}

Alamsyah, S. (2017). Pengaruh Profitabilitas terhadap Nilai Perusahaan, Relevansi Nilai Informasi Akuntansi, Keputusan Investasi, Kebijakan Dividen sebagai Variabel Intervening (Studi Empiris pada Perusahaan Indeks Kompas 100 Periode 2010-2013). Competitive Jurnal Akuntansi Dan Keuangan, Vol 1 (1), 136-161.

Andriani, L. (2018). Pengaruh Profitabilitas dan Pertumbuhan Penjualan terhadap Nilai Perusahaan dengan Kebijakan Deviden sebagai Variabel Intervening (Studi Empiris pada Perusahaan Sub. Sektor Property \& Real Estate yang Terdaftar di Bursa Efek Indonesia Tahun 2012 - 2016). Jurnal Ekobis Dewantara, Vol 1(7), 139-151.

Antoro, A. D., \& Hermuningsih, S. (2018). Kebijakan Dividen dan Bi Rate sebagai Pemoderasi Likuiditas, Profitabilitas, dan Leverage Terhadap Nilai Perusahaan Perbankan yang Terdaftar di BEI Tahun 2011-2017. Upajiwa Dewantara, Vol 2 (1), 5875.

Brigham, E.F, dan Houston, J.F. (2010). Dasar-dasar Manajemen Keuangan. Edisi 11. Terjemahan: Ali Akbar Yulianto. Jakarta: Salemba Empat.

Deviana, N., \& Fitria, A. (2017). Pengaruh Profitabilitas dan Keputusan Investasi terhadap Nilai Perusahaan melalui Kebijakan Dividen. Jurnal 
Ilmu Dan Riset Akuntansi, Vol 6 (3), 1148-1168.

Hanafi, Mamduh .M. (2015). Manajemen Keuangan. Edisi 1. Yogyakarta: BPFE.

Kasmir, (2014). Analisis Laporan Keuangan. Edisi 1. Jakarta: Rajawali Pers.

Martha, L., Sogiroh, N. U., Magdalena, M., Susanti, F., \& Syafitri, Y. (2018). Profitabilitas dan Kebijakan Dividen terhadap Nilai Perusahaan. Jurnal Benefita, Vol 3 (2), 227-238.

Murhadi, W. R. (2013). Analisis Laporan Keuangan Proyeksi dan Valuasi Saham. Edisi 1. Jakarta: Salemba Empat.

Nur,T.(2018).Pengaruh Growth Opportunity, Profitabilitas dan Struktur Modal Terhadap Nilai Perusahaan dengan Dividen sebagai Variabel Intervening pada Perusahaan Manufaktur yang Terdaftar di BEI pada Periode 20142017. Jurnal Manajemen dan Bisnis Indonesia, Vol 5 (3), 393-411.

Oktrima, B. (2017). Pengaruh Profitabilitas, Likuiditas, dan Struktur Modal terhadap Nilai Perusahaan (Studi Empiris: PT. Mayora Indah, Tbk. Tahun 2011 - 2015). Jurnal Sekuritas, Vol 1 (1), 98-107.

Permata, I. S., Kertahadi, \& Topowijono. (2013). Penilaian Saham dengan Menggunakan Metode Price Earning Ratio (PER) dan Price Book Value (PBV). Jurnal Administrasi Bisnis (JAB), Vol 2 (1), 65-73.

Puspitaningtyas, Z. (2017). Efek Moderasi Kebijakan Dividen dalam Pengaruh Profitabilitas terhadap Nilai Perusahaan Manufaktur. Jurnal Akuntansi, Ekonomi Dan Manajemen Bisnis, Vol 5 (2), 173-180.

Putra, A. N. D., \& Lestari, P. V. (2016). Pengaruh Profitabilitas, Likuiditas, dan Ukuran Perusahaan terhadap Nilai Perusahaan melalui Kebijakan Dividen. E-Jurnal Manajemen Unud, Vol 5 (7), 4044-4070.

Rachmawati, D., \& Pinem, D. B. (2015). Pengaruh Profitabilitas, Leverage dan Ukuran Perusahaan terhadap Nilai Perusahaan. Equity, Vol 18(1), $1-18$.

Sinarmayarani, A., \& Suwitho. (2016). Pengaruh Kepemilikan Institusional dan Profitabilitas terhadap Nilai Perusahaan melalui Kebijakan Dividen. Jurnal Ilmu dan Riset Manajemen, Vol 5 (5), 1-18.

Sudana, I Made, (2011). Manajemen Keuangan Perusahaan: Teori dan Praktik. Edisi 2. Jakarta: Erlangga.

Sugiono, (2015). Metode Penelitian Kuantitatif Kualitatif dan $R \& D$. Edisi 1. Bandung: Alfabeta CV

Sujoko, S., \& Soebiantoro, U. (2007). Pengaruh Struktur Kepemilikan Saham, Leverage, Faktor Intern dan Faktor Ekstern terhadap Nilai Perusahaan. Jurnal Manajemen dan Kewirausahaan, Vol 9 (1), 41-48.

Sumanti, J. C., \& Mangantar, M. (2015). Analisis Kepemilikan Manajerial, Kebijakan Hutang dan Profitabilitas terhadap Kebijakan Dividen dan Nilai Perusahaan pada Perusahaan Manufaktur yang Terdaftar di BEI. Jurnal Riset Ekonomi, Manajemen, Bisnis dan Akuntansi, Vol 3 (1), 1141-1151.

Wiyono, G., \& H. Kusuma, (2017). Manajemen Keuangan Lanjutan Berbasis Corporate Value Creation. Edisi 1. Yogyakarta: UPP STIM YKPN. 
